Rosana de Lima Soares I

\title{
Cultura das Mídias
}

1 Editora. Doutora em Ciências da Comunicação pela Escola de Comunicações e Artes da Universidade de São Paulo (ECA-USP). Professora de graduação no Departamento de Jornalismo e Editoração e de pósgraduação no Programa em Ciências da Comunicação da ECA-USP. Pesquisadora do Núcleo de Estudos em Linguagem e Mídia (ECA-USP), é autora do livro Imagens veladas. Aids, imprensa e linguagem (Annablume São Paulo, 2001) e de vários artigos publicados em revistas científicas.
As mídias, em sua multiplicidade de escritos e imagens, interpelam-nos todo o tempo em busca de respostas: estaremos chegando ao extremo de uma época marcada pela descontinuidade pós-moderna? Ou estaremos, ao contrário, retornando aos espaços mais familiares da modernidade?

Seria simples se pudéssemos escolher entre uma ou outra indagação. Na cultura contemporânea, entretanto, as dicotomias excludentes parecem não dar conta de responder a essas inquietações. Antes, são ainda outras questões que surgem a cada instante, instaurando a possibilidade de transitar, justamente, nas brechas abertas pelos múltiplos posicionamentos dos sujeitos.

Os artigos apresentados nesta Edição Especial da revista Caligrama foram escritos a partir de inquietações comuns, mas trazem a elas respostas singulares. Reunidos no Grupo de Trabalho "Cultura das Mídias" - integrante do XV Encontro Anual da Associação Nacional de Programas de PósGraduação em Comunicação (Compós), realizado entre os dias 06 e 09 de junho de 2006 na Unesp (Bauru-SP) -, os autores publicados nesta edição representam não apenas a diversidade teórica e metodológica do campo da Comunicação, mas também a pluralidade de vozes, lugares, espaços e instituições de nosso espaço acadêmico.

Um trajeto comum se delineia em meio à variedade, estabelecendo um território peculiar e mapeando fronteiras nas quais vemos surgir um jogo entre identidades e alteridades dos sujeitos, mediações e projeções das mídias. No movimento oscilante desses temas, vemos passar, no artigo de Vera Lúcia Follain de Figueiredo, as aventuras de Emília e Jeca Tatu na tecnosfera midiática, retomando as discussões sobre o nacional e o estrangeiro, o local e o global, o antigo e o novo. As imagens estrangeiras do Brasil e as representações brasileiras dos estrangeiros dão seqüência ao debate nos artigos de Paulo Cunha Filho e Alice Fátima Martins, abordando questões relativas ao espaço de semelhança e diferença propiciado pelos embates de cada um com todos os (seus) outros, debate este desenvolvido também no artigo sobre as figuras femininas (e feministas) mexicanas, de Mauricio de Bragança. 
Diversos campos do saber se cruzam nessas discussões, atravessando as fronteiras disciplinares da comunicação, dos estudos culturais, da psicologia social, da psicanálise, da linguagem, dos discursos verbais e audiovisuais. Esses cruzamentos se fazem presentes no texto de Mayra Rodrigues Gomes, que abre caminho para as tematizações sobre a produção audiovisual brasileira nos artigos de Renato Cordeiro Gomes sobre as matrizes culturais e os formatos industriais presentes na minissérie Hoje é dia de Maria; Solange Wajnman e Maria Gabriela Marinho, sobre a cultura visual e o consumo cultural antecipados pela telenovela Dancin' Days, Ana Lucia Enne e Kátia Fraga, sobre as práticas dialógicas e as comunidades midiáticas criadas no programa radiofônico Família Gazeta; e o artigo de Alfredo Suppia apresentando de forma ousada novas fronteiras para os gêneros cinematográficos brasileiros por meio da ficção científica. Finalmente, Rosana de Lima Soares aborda os espaços urbanos e as passagens identitárias propiciadas pelas paisagens midiáticas contemporâneas em filmes recentes do novo cinema brasileiro.

Como coordenadora do GT "Cultura das Mídias" e editora deste número especial, desejo que a leitura dos artigos - seus lugares de fala e espaços de silêncio - seja prazerosa e instigante. Nas tramas dos textos aqui reunidos apresentamos, ao mesmo tempo, a memória e o desdobramento de nossos debates, ato inaugural buscando gerar ainda muitos outros escritos e imagens. 